\title{
Perbandingan Pengaturan Rahasia Bank antara Indonesia dan Singapura
}

\author{
I Komang Santika ${ }^{1}$
}

${ }^{1}$ Program Magister (S2) Kenotariatan Fakultas Hukum Universitas Udayana,

E-mail: komangsantika88@yahoo.com

\begin{tabular}{l}
\hline Info Artikel \\
\hline Masuk : 21 Mei 2019 \\
Diterima : 15 Oktober 2019 \\
Terbit : 30 Desember 2019 \\
Keywords : \\
Bank Secret; Regulation; \\
Exceptions; Comparison. \\
\\
\\
Kata kunci: \\
Rahasia Bank; Pengaturan; \\
Pengecualian; Perbandingan. \\
Corresponding Author: \\
I Komang Santika, E-mail: \\
komangsantika88@yahoo.com \\
DOI : \\
10.24843/AC.2019.v04.i03.p06
\end{tabular}

\begin{tabular}{l} 
Abstract \\
The researh objectives to found the exception of opening bank \\
secrets in Indonesia and comparison of bank secret \\
arrangements between Indonesia and Singapore. This research \\
used the noemative method. Technique of data analiytical used \\
is the juridical analysis. The result of this study shown the \\
exceptions of opening bank secrets in Indonesia are regulated \\
in Article 41 until 44 A the Banking Act Year 1998 and \\
comparison of bank secret regulation in Indonesia and \\
Singapore indicates that these two countries provide exceptions \\
for opening bank secrets in some cases with relations to society, \\
justice, interests and state. \\
Abstrak \\
\hline Tujuan penelitian ini untuk menganalisis pengecualian \\
pembukaan rahasia perbankan Indonesia dan perbandingan \\
pengaturan rahasia bank antara Negara Indonesia dan \\
Singapura. Studi ini menggunakan metode normatif. Teknik \\
analisis data yang digunakan analisis yuridis. Hasil penelitian \\
menunjukkan pengecualian pembukaan rahasia bank di \\
Indonesia diatur pada Pasal 41 sampai dengan Pasal 44 A UU \\
Perbankan Tahun 1998 dan perbandingan pengaturan rahasia \\
bank di Indonesia dan Singapura menunjukkan bahwa kedua \\
negara ini memberikan pengecualian pembukaan rahasia bank \\
untuk beberapa kasus yang terkait dngan kepentingn keadilan \\
masyarakat dan negara.
\end{tabular}

\section{Pendahuluan}

Bank wajib memelihara rasa percaya masyarakat dengan cara rahasia bank hars selalu dijaga mengingat kepentingan masyarakat jika rahasia simpanan dananya selalu dijaga oleh bank. Kerahasiaan baik menjadi satu tonggak penting rasa percaya masyarakat kepada bank yang wajib selalu dipelihara secara terus menerus. Tonggak-tonggak yang lain meliputi prinsip hati-hati, kesehatan bank serta kepentingan adanya jaminan. Peraturan Perundang-Undangan yang mengatur bank adalah Undang-Undang Nomor 7 Tahun 1992 tentang Perbankan sebagaimana telah diubah dengan Undang-Undang Nomor 10 Tahun 1998 tentang Perubahan Atas Undang-Undang Nomor 7 Tahun 1992 tentang Perbankan (selanjutnya disebut UU Perbankan). Problem terkait dng kerahasian bank terkait dengan kerahasiaan bank diatur pada Bab Khusus mengenai kejahatan perbankan tepatnya pada Bab VII mengenai kerahasiaan bank. Hal ini menunjukkan kerahasiaan bank termasuk materi utama UU Perbankan. Pengaturan kerahasiaan bank ini menempatkan bank dalam kondisi antagonis. Pasal 40 UU 
Perbankan mewajibkan bank harus menjaga kerahasiaan nasabah yng menyimpan dana, namun di lain sisi Pasal 40 tersebut juga ada pengaturan tentang pengecualian keharusan membuka rahasia bank bagi penyidikan kejahatan/tindak pidana perbankan.

Ijin pembukaan rahasia bank diberikan oleh pimpinan Bank Indonesia (BI) dengan adanya permohonan seperti diatur oleh Pasal 41 hingga Pasal 44 UU Perbankan. Dalam praktik bank, terbukti bahwa ijin tersebut dengan mudah diberikan kepada penyidik yang mengajukan permohonan pembukaan rahasia bank. Setelah izin diterbitkan BI, bank tidak dapat menolak sebab berdasarkan Pasal 40 UU Perbankan itu, bank harus membuka rahasia bank.

UU Perbankan tidak mengatur, setelah kerahasiaan bank diizinkan dibuka penyidik, data nasabah penyimpanan masih jadi rahasia bank atau diubah jadi info publik. Dalam praktik rahasia bank yang sudah dibuka, ternyata oleh para penyidik; baik kejaksaan, kepolisian, ataupun pejabat Pusat Pelaporan dan Analisis Traksaksi Keuangan (PPATK); dipublikasikan oleh awak media dalam media massa, terutama di televisi. Bank dan nasabah kreditur tidak mendapatkan perlindungan hukum untuk mencegah publikasi yang merugikannya.

Pada praktik penyidikan tindak pidana perbankan, pada umumnya selalu diikuti pembukaan kerahasiaan bank. Celakanya penyidik seringkali semangat untuk memohon dibukanya kerahasiaan bank. Dalam hal ini seringkali digunakan oleh berbagai pihak dengan itikad tidak baik dalam rangka merubah nama baik bank serta nasabah penyimpanan dengan perbuatan melawan hukum yang secara formal diatur pada Pasal 41- 44A UU Perbankan.

Solusi sengketa pidana yang menyangkut bank pada pembuktiannya pada pengadilan selalu membuka kerahasiaan bank. Hal ini berdasarkan sifat dari hukum pidana yang ultimum remidium yang harusnya menjadi saranan terakhir diubah menjadi premium remidium atau sarana pertama pada penyelesaian sengketa bank yang seharusnya adalah sengketa perdata. Akibatnya nasabah penyimpanan dan bank rugi serta seluruh nasabah penyimpanan dengan itikad baikpun yang simpanannya bukan hasil tindak pidana, kerahasiaan simpanannyapun dipaksa dibuka atas dasar Pasal 44A UU Perbankan.

Ada sekelompok negara yang mengatur kerahasiaan bank sebagai aturan perdata khususnya kedalam hukum kontrak. Yang meliputi Amerika Serikat, Inggris, Australia, Kanada, Malaysia, Singapura, Belgia, Belanda serta yang lainnya. ${ }^{1}$ Di sisi lain ada kelompok negara yang memasukan pelanggaran aturan kerahasiaan bank menjadi problem pidana (criminal violation), yang meliputi Austria, Swiss, Perancis, Korea Selatan, Indonesia, Luxemburg, serta yang lainnya. ${ }^{2}$

Singapura yang merupakan negara tetangga Indonesia, menganut sistem hukum Common Law dan juga sangat sukses dengan jasa keuangannya. Pengaturan rahasia bank merupakan sumber ketertarikan para nasabah untuk mempercayakan kekayaannya kepada bank-bank Singapura. Karena ketertarikan masyarakat yang sudah sangat besar ini sehingga bank-bank Singapura menurut Sylvain Besson sebagaimana dikutip oleh Darid Chaikin dapat menerapkan biaya lebih besar dari

\footnotetext{
${ }^{1}$ Francis Neate dan Roger Mc Cormic. (2010). Bank Confiden Ality. London: Interna onal Bar Associa on, hal. 660

2 Dennis Cambell. (2010). Internaonal Bank Secrecy (General Edi On). London: Sweet \& Maxwell, hal. 663.
} 
kebanyakan bank ${ }^{3}$ dan memberikan bunga deposito yang lebih rendah dari kebanyakan bank lainnya. ${ }^{4}$

Berbeda dengan Singapura yang menganut sistem hukum Common Law, Indonesia yang menganut sistem hukum Civil Law menjadikan aturan pembukaan kerahasiaan bank sebagai persoalan hukum pidana. Menurut Muhammad Djumhana untuk nasabah penyimpan dana aturan yang menempatkan kerahasiaan bank sebagai hukum perdata sangat menarik dan membawa untung dibanding pengaturan sebagai hukum pidana mengingat kerahasiaan keuangan perusahaannya tidak diacak-acak oleh penyidik dan penyimpan dananya tidak dipidana. Dari sudut internal bank kewajiban merahasiakan keterangan tentang nasabahnya tidak diatur dalam kontrak penyimpanan dana di bank, namun pada umumnya dicantumkan dalam peraturan perusahaan tentang kewajiban pegawai bank untuk menjaga kerahasiaan keadaan keuangan nasabah sesuai dengan yang diperintahkan oleh UU Perbankan. ${ }^{5}$

Kondisi di atas menjadikan jika Kemenkumham tetap menjadikan aturan dibukanya kerahasiaan bank sebagai hukum pidana dapat mengakibatkan nasabah penyimpanan (investor) lebih memilih penempatan dananya ke luar Indonesia. Pemilik modal akan menempatkan modalnya pada rekening penampungan (escrow account). Pada negara lain, sementara itu bank di Indonesia hanya sebagai bank untuk melaksanakan usaha dengan jumlah kecil yang disesuaikan dengan kebutuhan. ${ }^{6}$ Hal yang menjadi kekhawatiran adalah nasabah kreditur yang sudah menyimpan dananya pada bankbank di Indonesia akan menarik dananya untuk selanjutnya disimpan di bank-bank di luar wilayah Indonesia (capital flight).

Asas rahasia bank mengharuskan bank agar merahasiakan informasi mengenai nasabah penyimpanan beserta dananya dengan tujuan agar nasabah terlindungi. Kerahasiaan bank dibutuhkan mengingat melalui kerahasiaan bank maka kepercayaan masyarakat kepada bank tercipta sehingga mau melakukan penyimpanan uang di bank. Kerahasiaan bank menjadikan bank sebagai lembaga yang bisa dipercaya. Bagi pihak yang menginginkan non-disclosure, kepentingan agar kerahasiaan bank dipegang teguh menjadikan nasabah penyimpanan percaya diri jika uang yang disimpan pada bank menjadi aman, bebas atas disalahgunakan pihak lain yang melakukan pencurian kondisi keuangan nasabah penyimpanan secara melawan hukum. ${ }^{7}$

Untuk pelaksanaan aturan kerahasiaan bank yang diatur pada UU Perbankan, dalam rangka perlindungan nasabah penyimpanan dari perbuatan melawan hukum dari informasi data nasabah terutama no hp dari nasabah, lembaga OJK meluncurkan Peraturan OJK No.1/POJK.07/2013 Tahun 2013. Pasal 19 Peraturan OJK menyebut: "Pelaku usaha jasa keuangan dilarang melakukan penawaran produk dan/jasa layanan kepada konsumen dan/atau masyarakat melalui sarana komunikasi pribadi tanpa persetujuan konsumen". Hal ini dapat ditafsirkan perusahaan pelayanan bidang keuangan tidak diperbolehkan menawarkan pelayanan serta produk pada pelanggan

${ }^{3}$ Darid Chaikin. (2005). Policy and Fiscal Effect of Swiss Bank Scerecy. Revenue Law Journal, Vol.15, Issue 1, Art 5, hal.97.

4 Mary English dan Wassim Shahin. (1994). Investigating the Interest Rate Impact of Changing Secret Bank Deposit Laws: Switzerland. Journal of Banking and Finance, Vol.18, Issue 3, hal. 461- 475.

${ }^{5}$ Muhammad Djumhana. (2008). Asas-Asas Hukum Perbankan Indonesia. Bandung: Citra Aditya Bakti, hal.169.

6 Tumbur M. Silalahi. (2015). Peran dan Kesiapan Perbankan Menghadapi Masyarakat Ekonomi ASEAN. Jurnal Ekonomi, Universitas Trisakti, hal. 27.

7 Yunus Husein. (2010). Rahasia Bank dan Penegakan Hukum. Jakarta: Pustaka Juanda Tigalima, hal. 38-49. 
serta publik dengan cara hubungan per person dengan tanpa persetujuan pelanggan. Sementara itu Pasal 31 ayat (1) Peraturan OJK Nomor 1/POJK.07/2013 Tahun 2013 mengatur bahwa: "Pelaku usaha jasa keuangan dilarang dengan cara apapun, memberikan data dan/atau informasi mengenai konsumennya kepada pihak ketiga". Hal ini dapat ditafsirkan bahwa pelaku usaha keuangan tidak dibolehkan secara apa saja menginformasikan data nasabah pada pihak ketiga. Pelarangan itu terkecuali pada (1) nasabah dengan ijin tertulis; dan/atau (2) diharuskan oleh peraturan perundangundangan. ${ }^{8}$

UU Perbankan memang belum secara jelas (norma kabur) mengatur mengenai rahasia bank, aturannya masih sebatas aturan umum pada lingkup "rahasia bank" yang diatur hanya pada Pasal 1 angka 28 UU Perbankan, yang mendefinisikan "rahasia bank meliputi segala sesuatu tentang nasabah penyimpan dan simpanannya". Dalam Pasal 40 ayat (1) UU Perbankan diatur bank harus merahasiakan informasi tentang nasabah penyimpan berikut simpanannya. Pelanggaran atas ketentuan ini diancam dengan pidana penjara dan denda (Pasal 47 ayat (1) UU Perbankan). Berdasarkan ketentuan tersebut bisa disimpulkan bahwa data informasi nasabah menjadi bagian dari seluruh data nasabah penyimpanan yang telah diberikan ke bank sewaktu perjanjian simpanan ditandatangani. Selain itu juga terdapat ketidakjelasan terkait dengan ketentuan hukum yang mengatur tentang pembukaan rekening suatu korporasi dimana tersangka atau terdakwa merupakan pengurus dari korporasi tersebut (norma kabur).

Berlandaskan pendahuluan ini, rumusan masalah pada studi ini terkait dengan kerahasiaan bank meliputi (1) Apa ada pengecualian pembukaan rahasia bank di Indonesia?; (2) Bagaimana perbandingan pengaturan rahasia bank antara Indonesia dan Singapura?.

Selanjutnya penelitian ini bermaksud untuk menganalisis pengecualian pembukaan rahasia bank di Indonesia; dan perbandingan pengaturan rahasia bank antara Indonesia dan Singapura.

\section{Metode Penelitian}

Penelitian ini menggunakan metode penelitian hukum yuridis normatif. Menurut I Made Pasek Diantha penelitian hukum normatif berfungsi untuk memberi argumentasi yuridis ketika terjadi kekosongan, kekaburan dan konflik norma. Lebih jauh ini berarti penelitian hukum normatif berperan untuk mempertahankan aspek kritis dari keilmuan hukumnya sebagai ilmu normatif. ${ }^{9}$ Jenis pendekatan yang digunakan adalah jenis pendekatan perundang-undangan (statute approach) dan pendekatan konsep (conceptual approach). Sumber bahan hukum yang diperlukan adalah bahan hukum primer, bahan hukum sekunder dan bahan hukum tertier. Mengenai teknik yang diterapkan dalam pengumpulan bahan hukum yang digunakan yaitu melalui teknik telaah kepustakaan (study document). Setelah melakukan penelusuran dan mengumpulkan bahan-bahan hukum dan perundang-undangan langkah selanjutnya membuat folder untuk menyimpan bahan yang sudah dikelompokkan sesuai dengan objek. Contohnya folder yang berisi peraturan

\footnotetext{
${ }^{8}$ Marnia Rani. (2014). Perlindungan Otoritas Jasa Keuangan terhadap Kerahasiaan dan Keamanan Data Pribadi Nasabah Bank. Jurnal Selat, Vol. 2, No. 1, hal. 62.

9 I Made Pasek Diantha. (2017). Metodologi Penelitian Hukum Normatif dalam Justifikasi Teori Hukum. Jakarta: Prenada Media Group, hal.12.
} 
perundang-undangan, teori, konsep dan sebagainya. Folder yang dimaksudkan adalah tempat untuk menyimpan ataupun menampung file-file dalam komputer. Folder yang telah dikelompokkan tersebut disimpan untuk memudahkan mencari bahan-bahan yang terkait dengan penelitian. Di dalam penelitian hukum normatif yang dianalisis bukanlah data, melainkan melalui bahan hukum seperti tersebut di atas. Dengan demikian, erat kaitannya antara metode analisis dengan pendekatan masalah. Analisis bahan hukum yang berhasil dikumpulkan dalam penelitian ini akan dilakukan secara deskriptif, evaluatif dan argumentatif.

\section{Hasil dan Pembahasan}

\subsection{Pengecualian Pembukaan Rahasia Bank di Indonesia}

\subsubsection{Konsep dan Tujuan Rahasia Bank}

Peristilahan kerahasiaan bank merupakan kerahasiaan antara hubungan bank dan nasabah. Sementara itu kerahasiaan lainnya yang tidak termasuk kerahasiaan bank dan nasabah, meskipun mempunyai sifat "rahasia", contohnya data hasil pengawasan bank atau data audit seperti diatur pada Pasal 30 ayat (3) serta Pasal 33 UU Perbankan ${ }^{10}$. Rahasia bank menurut Pasal 1 angka 28 UU Perbankan mengatur "semua hal terkait dengan informasi tentang perbankan yang mempunyai dana berikut dananya".

Definisi kerahasiaan perbankan pada UU Perbankan terlihat sangat umum serta mempersempit definisi kerahasiaan bank perbankan yang diatur pada UU Perbankan merupakan hal-hal terkait dengan dana serta perihal lain atas pelanggan perbankan yang sesuai hal lain oleh bank harus disimpan rahahasiannya.

Terdapat adanya 2 teori mengenai kerahasiaan bank yakni sebagai berikut: ${ }^{11}$

1. Absolut Theoritical (teoritis absolut dari kerahasiaan perbankan)

Berdasarkan teoritis ini perbankan memiliki keharusan untuk menyimpan kerahasiaan dari informasi-informasi terkait pelangarannya yang disimpan perbankan dikarenakan aktivitas perusahaan dalam kondisi apa saja. Teoritis itu memfokuskan sekali pada kebutuhan personal serta mengabaikan kebutuhan pemerintah serta publik.

Teori berpendapat kerahasiaan perbankan sifatnya absolut. Kerahasiaan perbankan tidak bisa disingkap dengan hukum ataupun UU. Semua informasi terkait nasabah bank berikut simpanannya yang ada pada perbankan harus dijaga kerahasiaannya tidak ada kecuali serta batasannya. Jika ada yang melanggar atas rahasia bank itu, maka bank yang bersangkutan wajib mempertanggungjawabkan semua akibat hukum yang muncul karenanya. Teori ini sangat individual yang membedakan hak kepentingan individu yang mana kebutuhan pemerintah serta publik disampingkan oleh kebutuhan personal yang membuat masyarakat dan/atau negara mengalami kerugian. ${ }^{12}$

2. Teori Kerahasiaan Perbankan yang sifatnya relatif

\footnotetext{
${ }^{10}$ Munir Fuady. (2009). Hukum Perbankan Modern. Edisi Revisi. Bandung: PT. Citra Aditya Bakti, hal. 89.

11 Hermansyah. (2012). Hukum Perbankan Indonesia. Edisi Revisi. Jakarta: Kencana, hal.132- 133.

12 Zainal Asikin. (2015). Pengantar Hukum Perbankan Indonesia. Jakarta: PT RajaGrafindo Persada, hal. 176
} 
Berdasarkan teori ini perbankan diizinkan menyingkap kerahasiaan ataupun memberi informasi terkait pelanggannya semua bagi kebutuhan pemerintah atau kebutuhan legal. Pengaturan kerahasiaan perbankan dikecualikan bagi tujuan termasuk bagi instruksi ataupun lembaga yang diizinkan minta informasi dan/atau keterangan mengenai kondisi dana pelanggan bank berdasarkan pengaturan perundang-undangan saat ini.

Teoritis relatif memberi perlindungan bagi yang memiliki uang tidak halal dalam rekeningnya, tapi di lain sisi teori ini memiliki rasa adil yang tidak mengesampingkan kebutuhan publik dan pemerintah dengan demikian saja, dimana kerahasiaan perbankan diatur pada UU Perbankan yang memberi perlindungan pada seluruh pihak yang terlibat.

UU Perbankan dikaitkan dengan pembahasan di atas, pengaturan kerahasiaan bank saat ini di Indonesia berpedoman pada teori yang sifatnya nisbi. Kondisi tersebut bisa ditemukan pada Pasal 40 ayat (1) UU Perbankan yang mengatur bahwa "Bank wajib merahasiakan keterangan mengenai nasabah penyimpan dan simpanannya, kecuali dalam hal sebagaimana dimaksud dalam Pasal 41, Pasal 41A. Pasal 42, Pasal 43, Pasal 44, dan Pasal 44A ayat (2) ketentuan sebagaimana dimaksud dalam ayat (1) berlaku pula bagi pihak terafiliasi". Ketentuan ini dapat diartikan peraturan kerahasiaan perbankan penerapannya dikecualikan pada perihal seperti diatur Pasal $41 \mathrm{~s} / \mathrm{d}$ Pasal 44A UU Perbankan. Kondisi ini artinya keberhasilan perbankan di Indonesia tidak bersifat absolut. ${ }^{13}$

Sementara itu tercantumkan pada penjelasan Pasal 40 ayat (1) UU Perbankan jika pelanggan penbankan merupakan pelanggan dng simpulkan mengungkap penerima kredit, pihak perbankan harus menjaga kerahasiaan informasi terkait pelanggan yang mempunyai kedudukan pelanggan yang menyimpan uangnya. Pada keterangan ayat tadi, dikatakan juga informasi terkait pelanggan di luar dari pelanggan yang menyimpan dananya, tidak menjadi informasi yang harus dijaga kerahasiaannya oleh perbankan. Dari penjelasan ini bisa disimpulkan informasi atau keterangan yang dimaksudkan yang harus dirahasiakan oleh bank merupakan seluruh informasi yang ada hubungannya dengan nasabah penyimpan berikut simpanannya. ${ }^{14}$

Peraturan kerahasiaan bank diperuntukkan agar kepentingan nasabah penyimpan dapat dilindungi, yang meliputi kondisi keuangan nasabah yang bersangkutan. Selainnya peraturan kerahasiaan bank untuk kepentingan bank sendiri supaya bisa dipercaya dan kelangsungan hidup bank terjamin. Di Indonesia, ketentuan kerahasiaan bank lebih ditekankan terhadap alasan untuk kepentingan bank, yang dapat dilihat pada penjelasan Pasal 40 UU Perbankan yang mengatur kerahasiaan bank dibutuhkan untuk keperluan perbankan saja yang membutuhkan kepercayaan masyarakat yang memiliki simpanan pada perbankan. Terdapat lima argumen sebagai dasar keharusan perbankan agar menjaga kerahasiaan seluruh informasi terkait dengan nasabah dan simpanan sebagai berikut:

a. Personal Privacy

b. Hak yang terbit dengan terjadinya perjanjian nasabah dengan bank

${ }^{13}$ Gagah Satria Utama. (2017). Pengecualian Rahasia Perbankan di Era Automatic Exchange Of Information (AEOI). Jurnal Business Law Community, Vol. 2, No. 1, hal. 15

${ }^{14}$ Adrian Sutedi. (2011). Hukum Perbankan Suatu Tinjauan Pencucian Uang, Merger, Likuidasi, dan Kepailitan. Jakarta: Sinar Grafika, hal. 8. 
c. Peraturan perundang-undangan

d. Kepatuhan dan kebiasaan pada kalangan bank.

e. Ciri khas perusahaan perbankan institusi yang dapat dipercaya yang wajib mempertegas rasa kepercayaan pelanggan penyimpan. ${ }^{15}$

\subsubsection{Pembukaan Kerahasiaan Perbankan Indonesia}

Asas yang menjadi dasar aturan kerahasiaan bank di Indonesia termasuk teori nisbi, yang mana maka teori nisbi ini dimungkinkan diberikannya informasi dan data terkait rahasia bank pada pihak ketiga. ${ }^{16}$ Aturan Pasal 40 ayat (1) UU Bank, ada yang dikecualikan dari peraturan kerahasiaan perbankan. Istilah pengecualian bisa berarti ada batas diberlakunya kerahasiaan perbankan. Atas dasar Pasal 40 ayat (1) tadi, perbankan tidak boleh merahasiakannya (bisa membukanya) pada hal-hal yang meliputi : 17

1. Untuk Kepentingan Pajak

Dikecualikan dari kerahasiaan perbankan dapat dijumpai pada Pasal 40 ayat (1) UU Perbankan, mengatur dasarnya harus merahasiakan informasi terkait pelanggan yang mempunyai serta dananya, terkecuali pada kondisi yang diatur pada Pasal 41, sampai dengan Pasal 44A. Istilah "pengecualian" ditafsirkan sebagai batasan atas keberlakuan kerahasiaan bank. Terkait informasi yang diatur pada ketentuan-ketentuan tersebut perbankan bisa membuka kerahasiaan bank (dapat membukanya). ${ }^{18}$

Untuk keperluan pajak kerahasiaan bisa diungkapkan, dimana perihal itu bisa dijumpai pada Pasal 41 ayat (1) UU Perbankan sebagai berikut :

“Untuk kepentingan perpajakan, Pimpinan Bank Indonesia atas permintaan Menteri Keuangan berwenang mengeluarkan perintah tertulis kepada bank agar memberikan keterangan dan memperlihatkan bukti-bukti tertulis serta surat-surat mengenai keadaan keuangan nasabah penyimpan tertentu kepada pejabat pajak".

Instruksi berbentuk tulisan di atas berdasarkan Pasal 41 ayat (1) UU Perbankan wajib mengandung/menyebutkan secara tertulis nama pegawai pajak serta pelanggan wajib pajak yang informasinya dibutuhkan.

2. Bagi Kepentingan Penyelesaian Piutang Bank

Pengecualian ke-2 atas rahasia bank diatur pada Pasal 41A yang menjadi tambahan aturan kerahasiaan bank dalam UU Perbankan yang mengatur untuk penyelesaian piutang bank yang telah diserahterimakan pada Badan Urusan Piutang dan Lelang Negara/Panitia Urusan Piutang Negara (BUPLN/PUPN), Pimpinan BI memberikan ijin pada petugas PUPN/BUPLN agar mendapatkan informasi dri perbankan terkait pelanggan penyimpanan beserta simpanannya.

15 Ibid, hal. 146-147.

16 Yunus Husein, op.cit, hal.193.

17 Neni Sri Imaniyati dan Panji Adam Agus Putra. (2016). Pengantar Hukum Perbankan Indonesia. Bandung: PT Refika Aditama, hal. 210-212.

18 Rani Sri Agustina. (2017). Rahasia Bank. Bandung: CV KENI Media, hal. 131. 
3. Bagi Kepentingan Pengadilan Kejahatan

Pada Pasal 42 UU Bank diatur mengenai:

(1) Untuk kepentingan peradilan dalam perkara pidana, Pimpinan Bank Indonesia dapat memberikan izin kepada polisi, jaksa atau hakim untuk memperoleh keterangan dari bank mengenai simpanan tersangka atau terdakwa pada bank.

(2) Izin sebagaimana dimaksud dalam ayat (1) diberikan secara tertulis atas permintaan tertulis dari Kepala Kepolisian Republik Indonesia, Jaksa Agung, atau Ketua Mahkamah Agung.

(3) Permintaan sebagaimana yang dimaksud dalam ayat (2) harus menyebutkan nama dan jabatan polisi, jaksa atau hakim, nama tersangka/terdakwa, alasan diperlukannya keterangan dan hubungan perkara pidana yang bersangkutan dengan keterangan yang diperlukan.

Berdasarkan ketentuan Pasal 42 UU Bank tersebut di atas, maka dapat disimpulkan bahwa perizinan untuk membuka rahasia bank diberikan dalam bentuk tulisan atas permohonan dalam bentuk tulisan Kapolri, Jaksa Agung serta Ketua Mahkamah Agung berikut menyebut orangnya dari kepolisian, kejaksaan dan kehakiman, yang disangka atau yang didakwa, alasan dibukanya informasi serta kaitannya dengan kejahatan yang dituduhkan beserta incformasi-informasi yang dibutuhkan.

4. Untuk Kepentingan Perkara Prdata

Pasal 43 UU Perbankan menyebutkan pada kasus perdata antara perbankan dengan pelanggannya, Direktur perbankan bisa memberi informasi pada pengadian dimuka hakim mengenai kondisi dana pelanggannya yang bersangkutan serta memberikan informasi lainnya berkaitan dengan kasusnya. ${ }^{19}$

5. Untuk Keperluan Tukar Menukar Informasi Antar Bank

Direksi bank, guna pertukaran informasi antarbank bisa menginformasikan kondisi keuangan nasabah pada bank lain. Pertukaran informasi antar bank ditunjukan demi kelancaran dan keamanan usaha bank yang meliputi pencegahan kredit double dan untuk tahu kondisi serta status bank lainnya. Jadi, bank bisa melakukan pemilihan atas risiko sebelum mengadakan transaksi dengan bank lain dan/atau nasabah. Pengaturan pertukaran informasi selanjutnya diatur oleh BI yang mengatur terkait tatacara permintaan informasi dan penyampaian dan bentuk serta jenis informasi yang bisa dipertukarkan, misalnya informasi terkait dengan kredit yang diperoleh nasabah, agunan serta kondisi debitur apakah termasuk dalam daftar kredit macet. ${ }^{20}$

\subsection{Perbandingan Pengaturan Rahasia Bank antara Indonesia dan Singapura}

\subsubsection{Pengaturan Kerahasiaan Bank di Indonesia serta Singapura}

\section{Pengaturan Kerahasiaan Perbankan di Indonesia}

\footnotetext{
19 Try Widiyono. (2006). Aspek Hukum Operasional Transaksi Produk Perbankan di Indonesia (Simpanan, Jasa, dan Kredit), Jakarta: Ghalia Indonesia, hal. 106.

${ }^{20}$ Marulak Pardede. (2005). Hukum Pidana Bank. Jakarta: Pustaka Sinar Harapan, hal.59.
} 
Aturan mengenai kerahasiaan perbankan pada UU Perbankan Tahun 1992 diatur pada Bab VII dari Pasal 40 hingga Pasal 45, sementara itu pada UU Perbankan yang berlaku saat ini yaitu UU Perbankan yang merupakan perubahan terhadap undang-undang tentang perbankan sebelumnya yakni UU Perbankan Tahun 1992 dicantumkan pada Pasal 40 hingga Pasal 45.

Adapun Pasal yang mengatur tentang rahasia bank dalam UU Perbankan adalah Pasal 40 yang mengatur:

a. Perbankan tidak boleh memberi informasi yang ada di perbankan mengenai kondisi dana serta perihal lainnya yang dimiliki pelanggannya, yang harus dijaga kerahasiaanya oleh perbankan berdasarkan kebiasaan kalangan Perbankan, terkecuali terkait dengan aturan Pasal 41 s/d Pasal 44 UU Perbankan.

b. Aturan seperti diatur pada ayat (1) juga diberlakukan pada pihak terkait.

Di dalam keterangan Pasal 40 UU Perbankan khususnya pada ayat (1) mengatur bahwa kaitan yang berdasarkan kebiasaan harus dijaga kerahaasiaannya oleh perbankan yaitu semua informasi data tentang semua hal terkait dengan dana serta perihal lainnya yang dimiliki pelanggan setra perusahaan yang mengerti perbankan oleh sebeb aktifitas perusahaannya. Rahasia ini dibutuhkan bagi keperluan perbankan yang membutuhkan rasa percaya dari publik yang memiliki simpanan dana pada perbankan.

Teori sebagai dasar kerahasiaan bank di Indonesia termasuk teori nisbi yang mana dalam teori nisbi dimungkinkan pemberian informasi dan data terkait rehasia bank kepada pihak ketiga. ${ }^{21}$

Pengecualian pengungkapan kerahasiaan bank sebagaimana telah dikemukkan di atas meliputi (a) Bagi keperluan pajak (Pasal 41); (b) Bagi pengahiran utangpiutang perbankan (Pasal 42A); (c) Bagi keperluan pengadilan kejahatan (Pasal 42); (d) untuk kepentingan pemeriksaan pengadilan prdata (Pasal 43); (e) untuk kepentingan pertukaran keterangan diantara perbankan (Pasal 44); (f) untuk keprluan orang lainnya yang ditunjuk pelanggan (Pasal 44A ayat (1); dan (g) untuk keperluan penyelesaian pewarisan (Pasal 44 ayat (2) UU Perbankan).

2. Pengaturan Rahasia Bank di Singapura

Singapura mempunyai aturan hukum Common Law dengan UU berbentuk tertulis yang dipandang sebagai perturan yang paling tinggi dari negara (Pasal 4 UndangUndang Dasar). Di Singapura, hubungan antara nasabah bank dan pegawai serta pemilik bank diatur oleh hukum common law. Namun, dalam hal tertentu, terutama mengenai aturan rahasia bank, diatur dalam Singapura Bank Law (Cap 19, 2008 RevEd) yang berlaku. Undang-undang ini pertama kali diundangkan pada tanggal 1 Januari 1971 dan beberapa kali mengalami perubahan revisi pada tahun 1985, 1994, 1999, 2003 dan terakhir adalah edisi revisi 2008 yang ditetapkan pada tanggal 6 Februari 2008. Pengaturan hubungan antara bank dan pelanggan sangat penting karena menimbulkan hak dan kewajiban seorang bankir. Dalam skenario yang paling umum, hubungan bank dan pelanggan mulai terjadi pada pembukaan rekening oleh nasabah bank.

21 Yunus Husein, op.cit, hal. 193 
Selain edisi revisi pada Singapore Banking Act, Undang-Undang ini juga mengalami beberapa kali amandemen. Salah satu amandemen yang berkaitan dengan pengaturan rahasia bank adalah yang terjadi pada tahun 2001. Undang-Undang Perbankan (Amandemen) 2001 mencabut Pasal 47 dan kembali diundangkan dalam bentuk yang berbeda secara substansial.

Larangan pengungkapan rahasia bank di Singapura yang dijelaskan dalam Pasal 47 Singapore Bank Law (Cap19,2008RevEd) menggunakan istilah "customer information" (informasi pelanggan). Pasal 40A undang-undang Singapura. Dari ketentuan tersebut tampak yang termasuk pada batasan kerahasiaan perbankan untuk pelanggan yang mempunyai dana ialah menyangkut informasi mengenai rekening nasabah tersebut lengkap dengan informasi mengenai simpanannya. Sedangkan untuk nasabah debitur, yang termasuk dalam aturan rahasia bank hanyalah informasi mengenai rekeningnya saja, tidak termasuk informasi mengenai dana yang dipinjamnya.

S. Ramesh mendiskripsikan bahwa hukum Singapura mengatur pengecualian dalam rahasia bank dengan sangat lengkap, bahkan dipisahkan pihak sebagai penerima informasi yang tidak dilarang untuk menyebarkan informasi yang ia dapat (Bagian I Third Schedule Singapore Banking Act) dan pihak sebagai penerima informasi yang dilarang menyebarkan informasi rahasia bank kepada orang lain kecuali telah ditentukan dalam undang-undang atau dengan perintah dari pengadilan. ${ }^{22}$

\subsubsection{Perbandingan Pengaturan Rahasia Bank antara Indonesia dan Singapura}

Berdasarkan peraturan rahasia bank di Indonesia dan Singapura, maka tampak bahwa kedua negara ini memberikan pengecualian pembukaan rahasia bank untuk beberapa kasus yang berkaitan dengan kepentingan keadilan masyarakat dan negara. Dengan demikian, maka dapat dinyatakan bahwa Indonesia dan Singapura dalam pengaturan rahasia bank bersifat relatif, sesuai dengan teori relatif (relative theory) dan telah memenuhi rasa keadilan (sense of justice).

Rahasia bank di Indonesia diperbolehkan dibuka untuk beberapa kasus tertentu diantaranya yang diatur pada UU Bank yakni terkait dengan Pajak (Pasal 41), bagi pengakhiran piutang bank (Pasal 41A), bagi peradilan pidana (Pasal 42), untuk beracara di pengadilan perdata (Pasal 43), untuk kepentingan pertukaran informasi antar bank (Pasal 44), untuk kepentingan pihak ketiga yang disetujui nasabah (Pasal 44A ayat (1) dan baagi penyelesaian sengketa pewarisan (Pasal 44A ayat (2). Pasalpasal ini juga menjelaskan mengenai prosedur yang dapat ditempuh untuk pengecualian pengungkapan rahasia bank beserta syarat-syarat yang harus dipenuhi dalam prosedur ini. Di luar kasus yang telah diterangkan dalam UU Perbankan di atas, terdapat pula beberapa pengecualian lain yang menjadikan rahasia bank boleh diungkapkan yakni untuk kasus yang berkaitan dengan kejahatan TPPU sesuai Pasal 33 ayat (2) Undang-Undang Nomor 25 Tahun 2003 tentang Tindak Pidana Pencucian Uang (selanjutnya disebut UU TPPU) dan juga untuk kasus yang terkait kejahatan korupsi sebagaimana dijelaskan dalam Pasal 12 Undang-Undang Nomor 20 Tahun 2001 tentang Tindak Pidana Korupsi (selanjutnya disebut UU Tipikor).

22 S. Ramesh. (2010). Govt's goal is to ensure all S'poreans Enjoy Fruits Of Growth: PM Lee. Channel News Asia, Vol.8, No.2, hal. 44. 
Hukum perbankan di Singapura mengatur pengecualian rahasia bank secara lengkap dalam Bagian I Third Schedule Singapore Banking Act. Pada pengaturan ini diatur secara terpisah mengenai informasi yang tidak dilarang untuk disebarkan dan informasi yang dilarang untuk disebabkan terkait dengan rahasia bank. Pembukaan rahasia bank dapat dilakukan jika telah diatur dalam undang-undang atau atas perintah pengadilan. Pengungkapan data nasabah yang diperbolehkan diatur dalam Bagian I Third Schedue Singapore Banking Act. Sedangkan pengungkapan informasi nasabah yang diizinkan yang termasuk dalam Bagian II Third Schedule Singapore Banking Act di mana informasi jenis lain tidak boleh disebarkan ke pihak lain. Larangan pengungkapan data rahasia bank ke berbagai pihak lain tetap berlaku meskipun yang bersangkutan sebagai penerima informasi sudah tidak bekerja lagi di bagian yang berurusan dengan kerahasiaan bank.

Dari penjabaran di atas terlihat bahwa Singapura memberikan penjelasan rinci terhadap jenis kasus yang diberikan pengecualian untuk dibukanya rahasia bank. Bahkan aturan ini jauh lebih maju dibandingkan aturan Indonesia yakni mengatur pula batasan yang diberikan kepada penerima informasi rahasia bank sehingga informasi yang dibuka tidak akan digunakan secara tidak bertanggung jawab oleh sang penerima informasi.

\section{Kesimpulan}

Peraturan kerahasiaan perbankan Indoesia tercantum pada Pasal 40 ayat (1) UU Perbankan Tahun 1992, yang mengatur adanya larangan bagi bank untuk memberi informasi nasabah yng ada pencatatan bank terkait kondisi keuangan nasabah serta informasi lain terkait nasabah yang harus dijaga kerahasiaannya oleh bank menurut kebiasaan dalam dunia perbankan, dengan pengecualian yang diatur pada Pasal 41 s/d Pasal 44 UU Perbankan 1992. Aturan tersebut dirubah semenjak terbitnya UU Perbankan Tahun 1998 menjadi bank harus merahasiakan informasi terkait nasabah penyimpan serta simpanannya, terkecuali seperti yang diatur pada Pasal $41 \mathrm{~s} / \mathrm{d}$ Pasal $44 \mathrm{~A}$.

Perbandingan pengaturan rahasia bank di Indonesia dan Singapura menunjukkan bahwa kedua negara ini memberikan pengecualian pembukaan rahasia bank untuk beberapa kasus terkait dengan rasa keadilan masyarakat dan negara. Dengan demikian, maka dapat dinyatakan bahwa Indonesia dan Singapura dalam pengaturan rahasia bank bersifat relatif, sesuai dengan teori relatif (relative theory) dan telah memenuhi rasa keadilan (sense of justice).

\section{Daftar Pustaka}

Buku

Agustina, Rani Sri. (2017). Rahasia Bank. Bandung: CV KENI Media.

Asikin, Zainal. (2015). Pengantar Hukum Perbankan Indonesia. Jakarta: PT RajaGrafindo Persada.

Cambell, Dennis. (2010). Internaonal Bank Secrecy (General Edi On). London: Sweet \& Maxwell.

Diantha, I Made Pasek. (2017). Metodologi Penelitian Hukum Normatif dalam Justifikasi Teori Hukum. Jakarta: Prenada Media Group. 
Djumhana, Muhammad. (2008). Asas-Asas Hukum Perbankan Indonesia. Bandung: Citra Aditya Bakti.

Fuady, Munir. (2009). Hukum Perbankan Modern. Edisi Revisi. Bandung: PT. Citra Aditya Bakti.

Hermansyah. (2012). Hukum Perbankan Indonesia. Edisi Revisi. Jakarta: Kencana.

Husein, Yunus. (2010). Rahasia Bank dan Penegakan Hukum. Jakarta: Pustaka Juanda Tigalima.

Imaniyati, Neni Sri dan Putra, Panji Adam Agus. (2016). Pengantar Hukum Perbankan Indonesia. Bandung: PT Refika Aditama.

Neate, Francis dan Cormic, Roger Mc. (2010). Bank Confiden Ality. London: Interna onal Bar Associa on.

Pardede, Marulak. (2005). Hukum Pidana Bank. Jakarta: Pustaka Sinar Harapan.

Sutedi, Adrian. (2011). Hukum Perbankan Suatu Tinjauan Pencucian Uang, Merger, Likuidasi, dan Kepailitan. Jakarta: Sinar Grafika.

Widiyono, Try. (2006). Aspek Hukum Operasional Transaksi Produk Perbankan di Indonesia (Simpanan, Jasa, dan Kredit), Jakarta: Ghalia Indonesia

\section{Jurnal}

Chaikin, Darid. (2005). Policy and Fiscal Effect of Swiss Bank Scerecy. Revenue Law Journal, Vol. 15, Issue 1, Art 5.

English, Mary dan Shahin, Wassim. (1994). Investigating the Interest Rate Impact of Changing Secret Bank Deposit Laws: Switzerland. Journal of Banking and Finance, Vol.18, Issue 3.

Ramesh, S.. (2010). Govt's goal is to ensure all S'poreans Enjoy Fruits Of Growth: PM Lee. Channel News Asia, Vol.8, No.2.

Rani, Marnia. (2014). Perlindungan Otoritas Jasa Keuangan terhadap Kerahasiaan dan Keamanan Data Pribadi Nasabah Bank. Jurnal Selat, Vol. 2, No. 1.

Silalahi, Tumbur M. (2015). Peran dan Kesiapan Perbankan Menghadapi Masyarakat Ekonomi ASEAN. Jurnal Ekonomi, Universitas Trisakti.

Utama, Gagah Satria. (2017). Pengecualian Rahasia Perbankan di Era Automatic Exchange Of Information (AEOI). Jurnal Business Law Community, Vol. 2, No. 1.

\section{Peraturan Perundang-Undangan}

Undang-Undang Nomor 7 Tahun 1992 tentang Perbankan.

Undang-Undang Nomor 10 Tahun 1998 tentang Perubahan Atas Undang-Undang Nomor 7 Tahun 1992 tentang Perbankan.

Undang-Undang Nomor 20 Tahun 2001 tentang Tindak Pidana Korupsi.

Undang-Undang Nomor 25 Tahun 2003 tentang Tindak Pidana Pencucian Uang.

Peraturan Otoritas Jasa Keuangan (POJK) Nomor 1/POJK.07/2013 Tahun 2013 tentang Perlindungan Konsumen Sektor Jasa Keuangan. 